Tax Structure, Size of Government, and the Extension of the Voting Franchise in Western Europe, 1860-1938

Toke S. Aidt and Peter S. Jensen

April 2007

CWPE 0715 


\title{
Tax Structure, Size of Government, and the Extension of the Voting Franchise in Western Europe, 1860-1938.*
}

\author{
Toke S. Aidt ${ }^{\dagger}$ and Peter S. Jensen ${ }^{\ddagger}$
}

April 12, 2007

\begin{abstract}
We study the consequences of the extension of the voting franchise for the size of (central) government and for the tax structure in 10 Western European countries, 1860-1938. We show, firstly, that the gradual relaxation of income and wealth restrictions on the right to vote contributed to growth in government spending and taxation. Secondly, we show that the impact of the franchise extension on the tax structure is conditional on tax collection costs. We find that the share of direct taxes (including the personal income tax) is positively affected by the franchise extension, but only if relative collection costs are below a given threshold. We use literacy as a proxy for the cost of levying a broad-based income tax.

Key words: Voting franchise, democracy, public finance, taxation.

JEL classification: D7, H1.
\end{abstract}

\section{Introduction}

The growth in the size of government that has characterized all industrialized countries in Europe, the USA and elsewhere over the past 150 years is a well-known fact documented by, e.g., Tanzi and Schuknecht (2000) and Lindert (2004a). As government spending

*We have benefited from comments made at the Meeting of the European Public Choice Society in Durham 2004 and at the World Congress of the Econometric Society in London 2005. We would also like to thank Michael Bordo, Martin Daunton, Andrew Harvey, Arye Hillman, Chris Meissner, Gaia Narciso, Susanne Neckermann, Hamish Low, Vania Sena, Helen Weeds, and Stanley Winer for helpful discussions and suggestions. We would also like to thank the Economic and Social Research Council for financial support (grant no. RES 000-22-1743).

${ }^{\dagger}$ Corresponding Author: Faculty of Economics, University of Cambridge, Cambridge CB3 9DD, United Kingdom. E-mail: toke.aidt@econ.cam.ac.uk. Phone: +44 1223 335231. Fax: +44 1223335475.

†Department of Economics, University of Aarhus, Building 322, DK-8000 Aarhus, Denmark. E-mail: psjensen@econ.au.dk. 
and taxation expanded during the late nineteenth and the early twentieth century major changes took place in the tax structure. Most notable was the rise of direct taxes including the personal income tax - and the decline of indirect taxes - including tariffs and excise duties - as the main source of revenue. These changes took place against the backdrop of democratization and significant advances in the institutional capacity to collect broad-based and complex taxes at low administrative costs. The process of democratization gradually removed income, wealth, and property qualifications on the right to vote for adult males, and later on gave voting rights to adult women. Improvements in the institutional capacity to collect taxes that lowered tax collection costs were brought about by a mixture of institutional reforms, the spread of elementary education, adaptation of modern record keeping, and economic and social progress in general. This reduced the transaction cost of collecting more complex taxes, such as the personal income tax, that required taxpayers to keep detailed records and the tax authorities to audit self-assessed tax returns.

The purpose of this paper is to analyze empirically the association between the extension of the franchise and improvements in tax collection technology on the one hand and the observed growth in the size of government and shift in the composition of tax revenues on the other. The paper is a companion to Aidt et al. (2006) that studies the consequences of the franchise extension for the composition of government spending and contributes with new historical evidence to the growing body of cross country studies of the economic and political determinants of fiscal systems (e.g., Riezman and Slemrod, 1987; Hettich and Winer, 1991; Kenny and Winer, 2006).

Our theoretical starting point is the probabilistic voting model and the Representation Theorem. ${ }^{1}$ The Representation Theorem stresses the interdependency of fiscal policy and implies that an extension of the franchise is associated with an adjustment of the entire fiscal system. Granting voting rights to a wider segment of society, including citizens who are relatively poor, enlarges the constituency of government and political parties respond by offering policy platforms that redistribute from rich to poor. The predicted consequence

\footnotetext{
${ }^{1}$ See Hettich and Winer (1988, 1999, chapter 4)
} 
is an increase in the size of government and an adjustment of the tax structure. The adjustment of the tax structure favored by the newly enfranchised voters to accommodate more spending and more redistribution depends critically on the relative tax collection costs. Without the capacity to levy income taxes, the burden of raising the extra revenue is likely to fall primarily on "old" indirect taxes, such a excise duties and customs. As relative tax collection costs fall, however, income taxes become an attractive alternative, both in terms of potential revenues and in terms of the capacity to redistribute income. More specifically, we test the following hypothesizes: (1) the extension of the franchise increases total spending and taxation ${ }^{2}$ and (2) the extension of the franchise increases the share of direct taxes where and when the cost of levying personal income taxes is low and has the opposite effect elsewhere.

Quantifying the impact of the extension of the franchise on the tax structure is of considerable interest in itself because it provides new systematic evidence that complements historiographical accounts of taxation in Western Europe (Webber and Wildavsky, 1986; Peters, 1991, Daunton 2001). It is, however, also of interest because it allows for new tests of the two hypothesizes outlined above. While the first hypothesis has been tested in a number of previous studies (see below), the second hypothesis regarding the interaction between tax collection costs and political rights has not been subject to empirical investigation before.

We test these hypotheses using historical data on the size and composition of central government tax revenues in a sample of 10 Western European countries for which we also have collected quantitative information on the extension of the voting franchise and a proxy variable for the capacity to levy income taxes for the period 1860-1938. Our preferred proxy variable is literacy measured as enrollment in primary education as in Riezman and Slemrod (1987). We estimate panel regressions that allow for unobserved country and time fixed effects as well as employing an instrumental variables approach. We find that the voting franchise, defined as eligible voters as a proportion of all citizens in the relevant age

\footnotetext{
${ }^{2}$ These tests are also of interest because recent theories of franchise extension, e.g., Acemoglu and Robinson (2000) and Boix (2003, chapter 1), are based on the premise that endogenous enfranchisement triggers similar consequences.
} 
and sex group, has a statistically significant positive impact on total government spending and total tax revenues out of GDP, as suggested by hypothesis 1. More importantly, we also find that the extension of the franchise has a statistically significant negative impact on the share of direct taxes when and where the capacity to levy income taxes fall below a critical threshold and a positive impact elsewhere. This is consistent with hypothesis 2 .

The paper contributes to the empirical literature on the political economy of fiscal systems in two main ways. Firstly, it contributes to the literature on the fiscal consequences of franchise extension. This literature explores variations in the franchise rules across time and space to identify the fiscal implications. Husted and Kenny (1997), for example, exploit differences in tax and literacy requirements during the period 1950-88 in US states and report evidence consistent with hypothesis 1 . Here, we focus on a historical sample of Western European countries during a period in which income, property and wealth qualifications were abolished. A similar quantitative historical approach is taken by Lindert (1994; 2004b) and Aidt et al. (2006). ${ }^{3,4}$ Secondly, a central aspect of the argument of this paper is that tax collection costs play an important role in understanding the political economy of fiscal choices. Peltzman (1980), Riezman and Slemrod (1987), Becker and Mulligan (2003), and Kenny and Winer (2006) also stress the role of relative tax collection costs as determinants of the size of government and the tax structure. Most recently, Dusek (2006) shows that income tax withholding, an important improvement in tax collection technology, can account for about 9 per cent of the growth in US state income tax revenues during the period 1940-70. We contribute to this literature by showing that tax collection costs play a pivotal role in understanding the impact of the franchise extension in Western Europe on the tax structure.

\footnotetext{
${ }^{3}$ Lindert (1994) estimates the impact of the franchise extension on the timing and spread of social programs in Western Europe and elsewhere during the period 1880-1930. Aidt et al. (2006) estimates the impact of the franchise extension on the scope of government spending in Western Europe during the period 1860-1938.

${ }^{4} \mathrm{~A}$ related literature, posing to test the so-called Meltzer-Richard hypothesis (Meltzer and Richard, 1981) that more uneven income distribution is associated with more redistribution and larger government, studies countries, states or municipalities where the franchise rules are fixed and then deduce the fiscal consequences directly from variations in the income of the median voter relative to the average taxpayer. This approach was taken by, for example, Meltzer and Richard (1983) and more recently, by Borge and Rattsoe (2004).
} 
The rest of the paper is organized as follows. In section 2, we discuss the institutional setting and present some facts. In section 3, we discuss the underlying theory and formulate two specific hypotheses to be tested. In section 4, we set out our empirical strategy. In section 5 , we report the results. In section 6 , we discuss the robustness of the results. In section 7 , we discuss some alternative interpretations of our results and conclude. The data appendix at the end discusses the construction of the data set and the sources.

\section{The Data and the Institutional Setting}

Our data tracks the evolution of voting rights, the tax structure and the level of public spending in 10 Western European countries covering the period from 1860 to $1938 .^{5}$ The countries in the sample are Belgium, Sweden, Norway, Denmark, the Netherlands, Germany, the United Kingdom ${ }^{6}$, France, Italy, and Switzerland. We have chosen to focus on these countries partly because comparable data is available, partly because their economic and political structures were fairly similar making panel analysis possible. The sample period is chosen to cover the years during which universal male suffrage emerged in Western Europe.

We classify taxes into three categories. The first category is direct taxes. This covers all forms of taxes that are levied on earnings, incomes, and profits of persons at the time at which they are earned, and include the (personal) income tax, property taxes, inheritance taxes, assessed taxes, land taxes, and corporation taxes. Indirect taxes are, in contrast, levied on those incomes when they are spent. We make a distinction between two categories of indirect taxes: customs and domestic market taxes. Domestic market taxes include excise duties and turnover taxes, while customs are taxes levied on international trade. During the nineteenth century, the dominant taxes were customs, excise duties, land taxes and inheritance taxes. These "old" taxes were gradually complemented and, in some cases, replaced by (personal) income tax and taxes on corporations and property. ${ }^{7}$

\footnotetext{
${ }^{5}$ For Germany and Italy, we have excluded the periods with National Socialist (1933-) and Fascist regimes (1923-), respectively. All fiscal data refer to central government.

${ }^{6}$ Not including Ireland.

${ }^{7}$ Turnover taxes were not introduced until late in the interwar period or after World War II.
} 
This general trend, of course, hides country differences. The United Kingdom, for example, introduced the (personal) income tax in 1842 many years before the other countries in the sample, and Switzerland did not raise any tax revenues from income taxes at the federal level until 1941. In Germany, the central government had, under the Constitution of 1871, no powers to levy direct taxes. This right was reserved for the States of the Federation, and it was not until the Weimar Republic that direct taxation became a significant source of central government revenue (Ritschl, 2003).

Excise duties were mostly levied on staple consumption goods such as tea, sugar, coffee, cacao, bread, soap, candles and similar products. After World War I, "sin" taxes on tobacco and alcoholic beverages, originally luxury consumption taxes, became popular and eventually became a burden for a broad segment of the population, as did the taxes on gasoline and motorcars introduced in the 1930s. These taxes were predominantly regressive and quite inefficient when levied at different rates on different goods. In contrast, the "oldest" of the direct taxes - the inheritance tax - was explicitly designed to be progressive. The same was true of the income tax when it was later introduced. In Sweden, for example, a personal and corporate income tax, supported by a coalition of small farmers and working men, was introduced in 1902. It applied an exemption for the first 1000 kroner at a time where average income was 992 kroner thereby exempting most individuals while requiring wealthy individuals to pay as much as 12 per cent of income in taxes in the years leading up to World War I (Webber and Wildavsky, 1986, p. 354). Similarly, during most of the nineteenth century, the income tax in the United Kingdom was only paid by the wealthy (Daunton, 2001). Yet, compared to the modern income tax, the ratio of the average individual income tax rate to the top tax rate was moderate. ${ }^{8}$ This feature kept deadweight costs down and made the personal income tax relatively efficient.

Customs played a dual role of raising revenues and protecting selected industries, often the agricultural sector. The move to free trade in some countries, notably the United Kingdom, the Netherlands and Belgium, in the first half of the nineteenth century reduced tariff barriers, but did not impact much on the share of revenues coming from customs (see

\footnotetext{
${ }^{8}$ Table 7 in Webber and Wildavsky (1986, page 344) lists top and bottom tax rates for a number of countries for the period 1799-1910.
} 
below). Many governments returned to protectionist policies in the 1880s and again in the interwar period. Trade taxes are often considered inefficient because the same revenue can be raised by taxing domestic and foreign goods of the same type at a single lower rate.

Table 1 records quantitative information on the tax structure in each of the 10 countries for three selected periods. We observe an increase in the share of (tax) revenues coming from direct taxation. On average 20.6 per cent of revenues came from direct taxes in the period before 1880; by the end of the 1930s, this had increased to 39.3 per cent. The overall trend is clear: the share of government resources collected as direct taxes was increasing. It is also interesting to note that it was customs revenues that gave way to more direct taxation, while the share of revenues from domestic market taxes was virtually unchanged at about 37-39 per cent through out the period.

$<$ Table 1: The evolution of total spending and the composition of taxes in 10 Western European countries, 1860-1938.>

The doctrine of a balanced budget was rigorously applied throughout the nineteenth century and was effectively the framework for public finances in Western European democracies till after World War II when Keynesian ideas of deliberately unbalanced budgets became generally accepted (Webber and Wildavsky, 1986, chapters 6 and 8). There were some exceptions, though, most notably Italy and Germany where peacetime spending and investments in arms were regularly financed by issuing debt, and France where some offbudget spending was financed by borrowing. In the other countries, however, the norm of balance was so widely accepted that when governments began to spend proportionately larger amounts for social programs and arms, they had to find new taxes to finance these expenses to maintain balance. An implication, then, is that taxing and spending were interdependent and this interdependence was an important factor affecting the formulation of fiscal policy (Webber and Wildavsky, 1986, p. 333). Table 1 also records the evolution of total government spending as a percentage of GDP. On average government spending out of GDP was 6.8 per cent at the beginning of the period; towards the end this figure had risen to 14 per cent: the size of government doubled between 1860 and 1938. The 
doctrine of a balanced budget implied a corresponding increase in total tax revenues.

The need for expansion of taxation to cover the increase in spending required reform of the tax administration. From 1870 onwards, all Western European countries had a professionalized administration, where public officials were selected on merit and paid salaries commensurate with responsibility and skill. The build-up of institutional know-how was greatly accelerated by World War I during which the size of government bureaucracies grew and their competency in extracting resources rose significantly (Webber and Wildavsky, 1986, p. 444). A consequence of this improvement in tax collection technology was that income taxation became feasible on an unprecedented scale. Taxation of income requires individuals to file a tax return and to keep detailed records of their incomes as well as an effective system for checking these returns and for insuring compliance. The development of tax collection capacity was, of course, part of a broader pattern of industrialization and economic development whereby individual incomes rose above subsistence and an increasing share of the population acquired the required skills and the willingness to fill in tax returns on a regular basis.

The period before World War II was an era of democratization in Western Europe. ${ }^{9}$ This was a complex process that over a 100 years period gradually broadened political participation and extended the franchise from being the privilege of the few to being the right of all adult citizens. The process can be quantified in many different ways. Our main interest is to study the consequences of the enfranchisement of poorer social groups, as opposed to enfranchisement of, say, women who would roughly represent a random sample from the income distribution. This can best be done by tracking the size of the electorate in percentage of its reference age and sex group over time and space. ${ }^{10}$ Before women's suffrage, the reference group is all men of voting age and after, it is all citizens of voting age. This measure, which we shall call suffrage, quantifies the consequences of income, property holding, and wealth restrictions on the right to vote in isolation from the

\footnotetext{
${ }^{9}$ Italy and Germany during the interwar period are, of course, examples of backlashes to democracy.

${ }^{10}$ Our data refer to the right to vote in parliamentary elections and where bicameral systems were in place, to elections for the lower chamber. We note that local and sub-national elections were often governed by a different franchise, as were the elections to the upper camber.
} 
effect of women's suffrage. ${ }^{11}$ We have plotted suffrage against time for the 10 countries in Figure 1. The trend towards universal suffrage is clearly illustrated by the data and was reached around 1925. The initial franchise, the speed with which it was extended and when the process was completed, however, differ considerably among the countries. The three panels of Figure 1 show three different types of franchise extension. Panel A shows how in Belgium, France and Norway the franchise was extended in one big reform. ${ }^{12}$ Panel B shows how the franchise in the United Kingdom, Italy, the Netherlands and Sweden was extended through a sequence of step-wise reforms. Panel $\mathrm{C}$ shows a pattern of gradual change which was followed in Switzerland, Germany and Denmark. ${ }^{13}$

$<$ Figure 1: The extension of the franchise in the 10 countries, 1800-1938>

\section{The Main Hypotheses}

We are interested in the link between the allocation of voting rights and the structure of the tax system. The focus on the tax system as opposed to a selected tax policy or fiscal outcome is important because it recognizes the interdependency among the choice of tax bases (and rates) and the size and scope of government. An implication, then, is that fiscal choices and the way these choices respond to an extension of the franchise are interdependent and can only be understood within a theoretical framework that can accommodate multi-dimensional policy spaces, such as the probabilistic voting model.

Within the framework of the probabilistic voting model, as adopted to the study of complex fiscal systems by Hettich and Winer $(1988,1999)$ and others, political parties compete for votes from heterogenous groups of voters without knowing for sure how voters cast their ballots. The equilibrium fiscal structure reflects a trade-off between the loss

\footnotetext{
${ }^{11}$ Carstairs (1980) provides a brief account of the relevant reforms in each country.

${ }^{12}$ The dip in suffrage in Norway between 1909 and 1915 is due to the fact that women whose husbands had incomes and wealth above a certain threshold were allowed to vote from 1909 onwards. This enfranchised about 50 percent of all women above 25 and thus reduced the fraction of the population of voting age entitled to vote. The remaining fraction of women of voting age was enfranchised in 1915. We have checked that this "anomaly" does not affect any of the results from our econometric analysis.

${ }^{13}$ These countries had no democratic institutions before 1871 (Germany), 1849 (Denmark) and 1848 (Switzerland) when one large reform enfranchised more than 50 per cent of the male population. Viewed in this way, these countries follow a pattern that is more like Belgium, Norway and France.
} 
and gain of political support from enfranchised groups of voters. ${ }^{14}$ By lifting property or income restrictions on the right to vote, individuals with lower incomes or less wealth are granted political voice, and the constituency of government is expanded with new voters who are poor relative to the average taxpayer. ${ }^{15}$ The Representation Theorem ${ }^{16}$, then, predicts that an extension of the franchise increases the demand for redistribution (Tridimas and Winer, 2005). This demand translates into policy through an adjustment of the structure of government spending and taxation.

Public expenditures, not only on welfare and social insurance, but also on public provision of private goods are powerful tools of redistribution. Welfare and social security is, typically, designed explicitly to benefit specific groups. Public provision of health, education, housing and similar services coexists with private provision and the fact that the state pays for subsidized housing or hospitals does not make it compulsory for individuals to use them. In consequence, these services often turn out to be redistributive: the rich pay for private, and higher quality, services and so consume little of what is publicly provided (Boadway and Marchand, 1995). It follows from the Representation Theorem that the extension of the franchise should be associated with more government spending, and we can formulate our first hypothesis as follows ${ }^{17}$

Hypothesis 1 The extension of the franchise increases total government spending (relative to GDP).

During the nineteenth and early twentieth century, balanced budget rules were, as noted

\footnotetext{
${ }^{14}$ Political parties may take the welfare of disenfranchised citizens into account in their policy choices, e.g., because they fear revolt (see, e.g., Acemoglu and Robinson, (2000)). However, enfranchisement induces political parties to pay more attention to these groups.

${ }^{15}$ This does not in itself explain why the franchise is extended. Justman and Gradstein (1999), Acemoglu and Robinson (2000), Boix (2003, chapter 1), Lizzeri and Persico (2004) develop alternative theories of franchise extension. They all, however, share the prediction that universal suffrage is associated with larger governments, either because of more redistribution or because of an expansion of provision of public goods. Congleton (2004) evaluates a number of alternative theories of franchise extension with a particular focus on the role of industrialization. We return to this in Section 4.

${ }^{16}$ The Representation Theorem shows that the equilibrium platform can be characterized by optimizing a particular weighted sum of the enfranchised voters utilities (Coughlin and Nitzan, 1981; Hettich and Winer, 1999, chapter 4).

${ }^{17}$ The median voter models, as developed by, for example, Meltzer and Richard (1981), Boix (2001) and Borge and Rattsoe (2004), also predict that the extension of the voting franchise is associated with redistribution from the rich to the poor and with an increase in the size of government, but these models are not well-suited for the study of the implications for the fiscal system as a whole.
} 
above, rigorously applied in most Western European countries. This provided a direct, contemporaneous link between the expenditure and revenue side of the government budget: higher spending needed to be financed by more tax revenues. An implication of hypothesis 1 , then, is that ways to raise the extra revenue must be found. The tax package that achieves this end most effectively depends on may factors, including the size of different tax bases, how elastic each tax base is (including how easy it is to evade tax payment), and differential administrative costs. In addition to this expenditure-driven adjustment of the tax structure, the Representation Theorem also suggests that the equilibrium tax structure itself becomes more redistributive.

In practise, the relative cost of collecting income taxes fell dramatically in the 80 years leading up to World War II as a consequence of new administrative capacity for assessing the incomes and profits of persons and corporations as they were earned and improvements in literacy and numerical skills of (potential) taxpayers. In societies that had developed the necessary capacity to levy and collect direct taxes at the time of franchise extension, e.g., because a broad segment of the population could read and write, new income taxes would be an effective way of raising the required revenues and an appealing way for political parties to extract revenues for redistributive purposes. Without the capacity to levy a broad-based income tax, the burden of generating the extra revenue would fall mostly on traditional taxes, such as excise duties and customs, with a large tax base and a wellestablished and relatively cheap system of collection already in place and revenue extraction would be limited to taxing commodities which are mostly or exclusively consumed by the rich or to property taxation. An attractive alternative to revenue extraction might, therefore, be tax-induced factor price manipulation. e.g., through trade protection. ${ }^{18}$

To take this prediction to the data, we need to make some assumptions. Based on

\footnotetext{
${ }^{18}$ The newly enfranchised voters need not, of course, benefit from trade protection. An extension of the franchise would according to standard Heckscher-Ohlin theory boost support for free trade in labourabundant countries and lower it in labour scarce economies. Insofar as most Western European countries were labour abundant and many voters under universal suffrage would be endowed mainly with labour, this line of reasoning would lead to the conclusion that the extension of the franchise leads to a lowing of tariffs and thus a reduction of tariff revenues (Mayer, 1984). In contrast, in situations where assetspecificity is important, voters whose income is directly or indirectly tied to sector specific factors would benefit from trade protection. O'Rourke and Taylor (2006) test some of these predictions.
} 
the historical record, it is reasonable to assume that direct taxes, including the personal income tax, profit, and inheritance taxes, were better suited for revenue extraction than the market taxes and customs in use. Moreover, because the personal income tax, when it became feasible by falling relative tax collection costs, were levied at relatively low and flat rates, the income tax was a relatively effective and efficient way of raising revenues. Although, the expansion of spending implies that all tax bases are likely to be pushed harder (Kenny and Winer, 2006), these theoretical arguments suggest that the franchise extension has a positive impact on the share of direct taxes in societies with the capacity to expand the collection of such taxes at low administrative cost. In societies without this capacity, we expect the share of indirect taxes to increase for two reasons. Firstly, these were the "old" taxes that could be relied on to generate the required revenues to finance the expansion of spending at moderate tax collection cost. Secondly, while yielding revenue, market taxes and customs could also be used to manipulate factor prices to the benefit of the newly enfranchised voters. We can summarize this as our second and main hypothesis:

Hypothesis 2 The extension of the franchise increases (decreases) the share of direct taxes and decreases (increases) the share of indirect taxes when and where the relative tax collection cost of income taxation is low (high).

To operationalize this hypothesis, we obviously need an empirical measure of "the capacity to levy income taxes" or, more generally, of relative tax collection costs. We postpone the discussion of this to the next section.

\section{Empirical Specification}

To test hypothesis 1 and 2, we estimate a panel model that consists of three sub-models. The first sub-model is a model of central government spending and tax revenue out of 
GDP. Here, we consider the following regressions

$$
\begin{aligned}
& \left(\frac{G}{Y}\right)_{i t}=\mu_{i}^{1}+\delta_{t}^{1}+\lambda^{1} t+\beta_{1}^{1} x_{i t}^{\text {suffrage }}+x_{i t}^{\text {control }} \boldsymbol{\beta}_{2}^{1}+\epsilon_{i t}^{1}, \\
& \left(\frac{T}{Y}\right)_{i t}=\mu_{i}^{2}+\delta_{t}^{2}+\lambda^{2} t+\beta_{1}^{2} x_{i t}^{\text {suffrage }}+x_{i t}^{\text {control }} \boldsymbol{\beta}_{2}^{2}+\epsilon_{i t}^{2},
\end{aligned}
$$

where $\left(\frac{G}{Y}\right)_{i t}$ is total spending as a percentage of GDP, $\left(\frac{T}{Y}\right)_{i t}$ is total tax revenues as a percentage of GDP in country $i$ at time $t, \mu_{i}^{k}$ is a country fixed effect, $\delta_{t}^{k}$ is a time fixed effect ${ }^{19}, t$ is a time trend, $x_{i t}^{\text {suffrage }}$ is the measure of the extension of the franchise (suffrage) introduced above, $x_{i t}^{\text {control }}$ is a vector of control variables to be discussed below, $\left(\lambda^{k}, \beta_{1}^{k}, \boldsymbol{\beta}_{2}^{k}\right)$ is the vector of parameters to be estimated, and $\epsilon_{i t}^{k}$ is a random error term with $E\left(\epsilon_{i t}^{k}\right)=0$ for $k=\{1,2\}$. Hypothesis 1 implies that $\beta_{1}^{1}>0$ and $\beta_{1}^{2}>0$.

The second sub-model is a model of the tax structure. By definition, the shares of direct, customs and domestic market taxes must sum to 100 per cent:

$$
\left(\frac{T_{1}}{T}\right)_{i t}+\left(\frac{T_{2}}{T}\right)_{i t}+\left(\frac{T_{3}}{T}\right)_{i t}=100
$$

where $T_{1}, T_{2}$ and $T_{3}$ denote the revenue from direct taxes, customs and domestic market taxes in country $i$ at time $t$, respectively. We consider for $j \in\{1,2,3\}$ the following tax share regressions:

$$
\left(\frac{T_{j}}{T}\right)_{i t}=v_{i t}^{j}+\alpha_{1}^{j} x_{i t}^{\text {suffrage }}+\alpha_{2}^{j} x_{i t}^{\text {cost }}+\alpha_{3}^{j} x_{i t}^{\text {cost }} x_{i t}^{\text {franchise }}+x_{i t}^{\text {control }} \boldsymbol{\alpha}_{4}^{j}+\varepsilon_{i t}^{j},
$$

where $v_{i t}^{j}=\eta_{i}^{j}+\omega_{t}^{j}+\theta^{j} t$ is the sum of a country fixed effect $\left(\eta_{i}^{j}\right)$, a time fixed effect $\left(\omega_{t}^{j}\right)$, and a time trend $(t),\left(\eta^{j}, \alpha_{1}^{j}, \alpha_{2}^{j}, \alpha_{2}^{j}, \boldsymbol{\alpha}_{4}^{j}\right)$ is the vector of parameters to be estimated, and $\varepsilon_{i t}^{j}$ is a random error term with $E\left(\varepsilon_{i t}^{j}\right)=0$. The variable $x_{i t}^{\text {cost }}$ is a measure of the capacity to levy income taxes or the relative tax collection cost of income taxes, and $x_{i t}^{\text {control }}$ is a vector of control variables (see below). The identity in equation (3) requires that the parameters on each of the time-varying variables in the tax share equations must sum to

\footnotetext{
${ }^{19}$ In the reported regressions, we include five years dummies. Since the panel is unbalanced year effects cannot be identified for the early parts of the panel and we decided to use five years effects to avoid this problem. The results are essentially unaffected if we instead use year effects (results can be obtain upon request).
} 
zero. ${ }^{20}$ Hypothesis 2 implies that $\alpha_{1}^{1}<0$ and $\alpha_{3}^{1}>0$ and that

$$
\frac{-\alpha_{1}^{1}}{\alpha_{3}^{1}} \in\left[\min \left\{x_{i t}^{\text {cost }}\right\}, \max \left\{x_{i t}^{\text {cost }}\right\}\right] .
$$

To implement this test, we need a proxy variable for the capacity to levy income taxes $\left(x_{i t}^{\text {cost }}\right)$. As argued above, this capacity emerged as societies became richer, tax payers acquired the skills needed to handle tax returns and the tax administration developed the capacity to audit and collect complex, broad-based taxes. Development of formal markets and adoption of modern recording systems were other important factors. A number of alternative proxies have been suggested in the literature. GDP per capita is one candidate. It captures the rise in average income, and is thus related to the base on which income taxes are levied. Yet, it is not a convincing proxy. While the trend growth of income is related to the share of individuals with incomes above subsistence and from whom one might extract income taxes, business cycle fluctuations mask this and it is not reasonable to presume that the underlying capacity to tax income fluctuates with the trade cycle. Moreover, as pointed out by Wagner (1883) and many others, GDP per capita captures many other facets of the process of industrialization, development and social progress that has nothing to do with tax collection capacity. An alternative suggested by Kau and Rubin (1981) is urbanization. The idea is that monitoring of tax compliance may be less costly in urban areas. However, while urbanization is positively linked to both the tax base on which income, property and sales taxes are levied, it is not clear that it is a good measure of relative tax collection costs. For example, without a proper census system, it might, in fact, be harder to tax incomes in a dynamic urban environment where individuals frequently change place of residence than in a more static rural environment. A similar argument can be made against using population density in a country as a whole, suggested by Riezman and Slemrod (1987), as a proxy.

We believe that the best available proxy variable is literacy and that the relative collection cost of income taxes depends negatively on the degree of literacy. This variable has been used successfully in a number of previous studies, including Riezman and Slemrod (1987) and Kenny and Winer (2006), and has much to commend it. Firstly, literacy and

\footnotetext{
${ }^{20}$ See Wooldridge (2002, pp. 167-169).
} 
basic numerical skills are necessary for filling tax returns and the spread of these skills in the population, therefore, reduces the cost of collecting taxes that require individuals and businesses to file a tax return and to keep detailed records. ${ }^{21}$ In short, a minimum level of literacy and numeracy is necessary for successful income taxation. As Riezman and Slemrod (1987, p. 546), who first proposed the proxy, point out: it "seems reasonable [that the relative collection cost of tariffs depends positively on literacy levels] because operating a tariff system requires a small number of educated civil servants, while income or sales taxation, to function effectively, requires the participation of a large number of educated people". Secondly, education is correlated with earnings, and average education attainment provides a measure of the earnings potential of the population that is independent of the business cycle. Income taxation is ineffective and costly if the vast majority of the population live on subsistence wages. As education levels improve, more people earn incomes above this level. This, in turn, reduces the cost of collecting taxes levied on income. Thirdly, it is easier (and cheaper) to recruit a well-qualified bureaucracy in societies with a larger pool of educated individuals. This, in turn, allows the government to build institutional capacities. We feel confident that literacy captures salient aspects of tax collection cost and we use data on the percentage of all 5-14 year-old children who attended school - enrollment rate - over time and space to proxy for the capacity to levy income taxes. However, education can be argued to proxy for other influences on fiscal outcomes, such as inequality and election turnout. We defer the discussion of this to Section 7.

In each regression, we include a number of time-varying control variables $\left(x_{i t}^{\text {control }}\right)$ that capture aspects of the economic, social and political environment in the 10 countries. First, the variable urbanization rate measures the proportion of the population who lives in towns or cities with more than 10,000 inhabitants. Urbanization is highly correlated with industrialization and economic and social progress - factors which in themselves are likely to affect the tax structure and which through the processes discussed by Wagner

\footnotetext{
${ }^{21}$ These tax returns were complex documents and it was not a simple matter to fill them in. An example of a tax return from 1887-88 from the United Kingdom can be viewed on http://www.econ.cam.ac.uk/ faculty/aidt/papers /papers2.htm.
} 
(1883) should increase the need for public services and for regulation of economic activity. The urbanization rate also captures, as pointed out by Kenny and Winer (2006), a variety of tax base effects because land is more valuable in urban areas and because urbanization leads to more specialization in trade. Second, the age composition of the population may also have an impact on the composition of tax revenues by affecting the composition of the population of taxpayers. Moreover, Lindert (1994) shows that the proportion of old individuals has a significant impact on the rise of social spending in Europe and the USA during the period 1880-1930, and we would, thus, expect the age structure to affect the size of government positively. We include the percentage of the population aged 65 or older, old, to allow for this possibility. Third, we include an estimate of PPP adjusted GDP per capita, gdp per capita, to control for business cycle effects and proxy for general development trends. This variable also captures tax base effects and is expected to affect the share of direct taxes positively. Fourth, we include enrollment rate in the regressions for total spending and taxes as a control variable. Finally, all regressions include a set of war dummies. ${ }^{22}$

Our focus is on the extension of the franchise and the associated shift the right to participation in the political process. This aspect of democratization is captured well by the variable suffrage. However, the process of democratization that started in the early nineteenth century was complex and had many other dimensions than political participation. Firstly, during the period institutional reforms induced more political competition for control of government and imposed more checks on the executive. To control for this, we include the polity IV index constructed by Marshall and Jaggers (2000) among the control variables. ${ }^{23}$ The index is measured on a scale from -10 (little political competition)

\footnotetext{
${ }^{22}$ One dummy variable is used to control for the impact of wars prior to World War I. To capture the impact of World War I, we introduce four additional "war dummies" for all the countries in the sample. These dummies cover the periods 1913-1915, 1915-17, 1917-19 and 1919-21 separately.

${ }^{23}$ The polity IV index summarizes different indicators of political authority patterns to measure three key aspects of a country's political system. The three aspects are: i) competitiveness and openness in the process of executive recruitment; ii) constraints on the chief executive and iii) competitiveness and regulation of political participation. A weighted sum of the components is used to construct two summary variables, measuring democracy on a scale from 0 to 10 and autocracy from -10 to 0 . The polity IV index is the sum of these two sub-indexes.
} 
to 10 (lot of political competition). ${ }^{24}$ Second, suffrage captures the effects of relaxing economic restrictions on the right to vote in isolation from women's suffrage. To control for the effect of women's suffrage, we include a dummy variable which is coded 1 in the years after women's suffrage and zero before that. Third, the extension of the franchise and the increase in political competition was associated with the establishment of new political parties. In particular, left-wing parties began to gain legislative representation in the last quarter of the nineteenth century and the first left-wing governments were formed after World War I (e.g., in the United Kingdom and Denmark). We include a measure of the seat share of left-wing parties (left-wing party share) in the regressions to control for the effect of this. Forth, all the countries in the sample with the exception of the United Kingdom changed their election system from one based on majority rule to one based on proportional rule. Persson and Tabellini (2000, chapter 8 and 9) and others have argued that the election rule has a systematic impact on fiscal outcomes and we control for this by including the dummy variable proportional rule which is equal to 1 in years where the election rule is proportional rule and zero otherwise.

The third sub-model is a model of the voting franchise. The dynamics of the voting franchise is affected by many factors. According to Lipset's (1960) modernization hypothesis higher income, the rise of education, urbanization and younger populations are major causes of democratization. Congleton (2004) stresses the role of industrialization. Janowitz (1976) argues that mass conscription armies contributed to the development of democratic political institutions. Justman and Gradstein (1999), Acemoglu and Robinson (2000) and Boix (2003, chapter 1) argue that social alienation or a direct threat of revolution played a pivotal role in triggering an extension of the franchise. Based on these theoretical arguments, we can specify the regression equation for $x_{i t}^{\text {suffrage }}$ as follows

$$
x_{i t}^{\text {suffrage }}=\chi_{i}+\varphi_{t}+\varkappa t+\gamma_{0} x_{i t-\tau}^{\text {suffrage }}+x_{i t}^{\text {control }} \gamma_{1}+\gamma_{2} r_{i t}+\xi_{i t}
$$

\footnotetext{
${ }^{24}$ To take into account that the polity IV index is not measured on a cardinal scale, we use, in the regressions, a dummy variable, polity IV dummy, which is equal to 1 if the polity IV index is positive (high degree of competition) and 0 if the polity IV index is negative (low degree of competition) rather than the index itself. The results are the same if the index itself is included in the regressions.
} 
where $\chi_{i}$ is a country fixed effect, $\varphi_{t}$ is a time fixed effect, $\varkappa t$ is a time trend and $\xi_{i t}$ is an error term with $E\left(\xi_{i t}\right)=0$. The vector $x_{i t}^{\text {control }}$ contains the same economic and social variables as in the fiscal sub-models. This include, to capture the possible effect of conscription armies, the full set of war dummies and a number of variables related to the modernization hypothesis. The variable $r_{i t}$ is a dummy variable coded 1 if a revolution or major revolt took place in one of the 10 countries or elsewhere in Europe in a particular year (revolution) and is not included in the fiscal sub-models. ${ }^{25}$ This variable is motivated by the theoretical model of Acemoglu and Robinson (2000) and is a crude attempt to quantify the (perceived) threat of revolution. Finally, the extension of the franchise depends on its own past value. This captures the strong path dependency in the evolution of franchise institutions in Europe.

We begin by estimating the fiscal model (equations (1) to (4)) under the assumption of conditional independence, i.e., that the observed variation in the extension of the franchise (and in tax collection technology) is exogenous conditional on the control variables included in the model. We use a fixed effects estimator to control for country-specific effects and include time effects (and a time trend) in all regressions to control for common shocks. ${ }^{26}$ This implies that we are using within variation to identify the fiscal effects of the franchise extension; in other words, our test of hypothesis 1 and 2 uses the time dimension for each country to estimate the relevant parameters. In effect, we are seeking an answer to the question: if a given country had extended the franchise, then, allowing for the country's tax collection capacity, what would we predict the likely change in the tax structure and in total taxation and spending to be. We allow for panel heteroskedasticity and for spatial correlations between the error terms across countries, and the reported standard errors of the parameter estimates are panels corrected standard errors (PCSEs), as recommended by Beck and Katz (1995). Since the German constitution of 1871 prevented the central government from levying direct taxes, we have excluded Germany in the main analysis, but show in the robustness analysis that this is not important for the results. In addition,

\footnotetext{
${ }^{25}$ With a full set of year dummy variables, the effect of revolution cannot be identified. Thus, the variable can only be include in the specification with 5 -years time effects.

${ }^{26}$ The model is estimated with STATA 9.2.
} 
since the tax shares are obviously bounded between 0 and 100, one can argue that a Tobit estimator that takes this into account is appropriate and we use this as an alternative to the fixed effect estimator.

To estimate the full model, we need to take equation (6) into account and, to this end, we reestimate the model using an instrumental variables approach. Equation (6) suggests that we can use revolution and the lagged value of the franchise as instruments. While the first variable is clearly rooted in theory, one might question whether the lagged value of the franchise is uncorrelated with any unobserved factor that affects the level and composition of taxes. ${ }^{27}$ We return to this important issue in Section 5.2.

\section{$5 \quad$ The Results}

We report the main results in Table 2. The results for total spending and total tax revenues out of GDP are reported at the beginning of the table followed by the results for the tax share model (estimated either with the fixed effects estimator or with the Tobit estimator). Table 3 shows the instrumental variables estimates.

$<$ Table 2: The main results $>$

\subsection{Main Results: The Fiscal Model}

Regressions (1) and (2) in Table 2 show that the data strongly support hypothesis 1: the coefficient on suffrage is highly significant in both regressions and positive. A country that transits from a very restricted to universal suffrage would experience an increase in total spending out of GDP of about 8 percentage points and a 2 percentage points increase in total tax revenues. These effects are similar to those reported in Aidt et al. (2006) and confirm a growing consensus that the extension of the franchise contributed positively to growth in government. ${ }^{28}$

\footnotetext{
${ }^{27}$ We use lags of three years. Under the assumption that the lagged value of suffrage is uncorrelated with unobserved components of spending, taxes and tax shares, this procedure produces consistent estimates in panels with a long time dimension. This, however, requires that the relevant error terms are uncorrelated over time.

${ }^{28}$ See, e.g., Husted and Kenny (1997), Boix (2001) and Lindert (2004b).
} 
Regressions (3) to (8) report the results for the tax share model. The results support hypothesis 2: the coefficient on suffrage in the regression for the share of direct taxes is negative and the coefficient on the interaction between suffrage and enrollment rate is positive and highly significant. This implies that there exists a critical value of our proxy for tax collection capacity such that a country below this value would see a reduction in the share of direct taxes (and an increase in the share of indirect taxes) as a consequence of the franchise extension, while a country with a tax collection capacity above the critical value would see its share of direct taxes go up following the extension of the franchise. The results are almost identical for the fixed effects and the Tobit estimator, ${ }^{29}$ and in the discussion, we focus on the results from the fixed effects regressions in columns (3) to (5). The critical value $\left(\frac{-\alpha_{1}^{1}}{\alpha_{3}^{1}}\right)$ is a school enrollment rate of around 62 per cent. In our sample, school enrollment varies from a minimum of 29 per cent to a maximum of 86 per cent, so the critical value is well within the range that we actually observe. To gauge the economic significance of these results, we can calculate by how much the tax structure would have changed as a consequence of the extension of the franchise in a hypothetical country with limited capacity to collect income taxes (high relative collection costs) and compare to another country which has developed this capacity (low relative collection costs). This is done in Figure 2. In the country with a limited capacity to levy income taxes (proxied by an enrollment rate of 54 per cent), the transition from autocracy to universal suffrage would have reduced the share of direct taxes by 13 percentage points. In the country with the capacity to levy income taxes (proxied by an enrollment rate of 74 per cent), the opposite happens and the share of direct taxes increases by 13 percentage points.

$<$ Figure 2: The impact of the extension of the franchise on the share of direct taxes in two hypothetical economies.>

The other side of the coin, of course, is that the share of indirect taxes decreases as voting rights are granted in countries with the capacity to levy income taxes and increases

\footnotetext{
${ }^{29}$ Strictly speaking, the marginal effects from the Tobit estimator need to be adjusted to make them comparable to the marginal effects from the fixed effects estimator (See e.g., Greene (2000)). This adjustment is, however, minor and we do not report it.
} 
in countries without this capacity. It is, however, interesting to note that the effect on customs is much larger than the effect on domestic market taxes. This suggests that the newly enfranchised voters or those who represented them in parliament in a country where income taxation was not an option tended to raise the extra revenue required to finance the expansion of public spending mainly through trade taxes. This result is consistent with the notion of factor price manipulation through trade protection, but could also be explained simply by the fact that taxes on imports (and exports) produce better yields at the margin than domestic market taxes.

It is of interest to conclude this section by comparing the results obtained for the tax share model with the existing cross country evidence for the period after World War II. Kenny and Winer (2006) report that falling relative tax collection costs, measured by average years of schooling, explain why some countries raise a larger share of taxes through individual income and goods \& service taxes than others during the period 1975-92, while Riezman and Slemrod (1987) show how differential collection costs, as measured by adult literacy, can explain the fraction of tax revenue accounted for by taxes on international trade. Our results - derived from a different time period and using "within" country variation rather than "between" country variation - point in the same direction, although the impact of tax collection cost, of course, is conditional on the degree of political participation. ${ }^{30}$ Kenny and Winer (2006) also investigate how differences in political and civil rights affect the tax structure. They find that the impact is non-linear and report that countries with more developed political and civil rights tend to raise more revenue through income taxation, but only once a certain threshold has been reached. We study a different aspect of democratization - political participation - and show that non-linear effects in the form of interactions between relative tax collection costs and the voting franchise are the key to understand how universal suffrage affected the tax structure historically in Western Europe.

\footnotetext{
${ }^{30}$ If we exclude the interaction term from the tax share model, enrollment rate is positively associated with the share of direct taxes and negatively associated with the share of tariff revenue [not reported].
} 


\subsection{Estimates: The Full Model}

Table 3 reports the results from the instrumental variables estimation using a fixed effects 2SLS estimator. As discussed above, we use $x_{i, t-3}^{\text {suffrage }}$ and revolution as instruments. In addition, the interaction between enrollment rate and suffrage should be treated as endogenous and so in estimating the tax share sub-model, we use the interaction between the lagged value of suffrage and enrollment rate as an additional instrument.

We report the results from the two first stage regression for $x_{i, t}^{\text {suffrage }}$ in regressions (9) and (12) respectively. ${ }^{31}$ We note that enrollment rate and old are significant determinants of the franchise with signs consistent with modernization theory. The war dummies (not shown) are not individually significant, although the point estimates are positive as suggested by Janowitz (1976). Jointly the instruments are highly significant in all first stage regressions with F-statistics well over 200. However, this is mainly driven by the lagged value of suffrage. Revolution is not in itself significant and enters with a negative point estimate. We also note from the table that the Hansen $\mathrm{J}$ test of overidentification is not rejected in all cases. Thus, insofar as revolution on a priori theoretical grounds is a valid instrument, these results suggest that we cannot reject the validity of the lagged value of suffrage (and its interaction with enrollment rate) as being valid.

Turning to the second stage regressions, the evidence in favour of hypothesis 1 is somewhat weakened: while suffrage continues to be positively associated with both measures of the size of government, the point estimate is not statistically significant in the regression for total tax revenues out of GDP. Hypothesis 2, on the other hand, continues to be strongly supported. We note though that the critical values $\left(\frac{-\alpha_{1}^{j}}{\alpha_{3}^{j}}\right)$ implied by the tax share model are slightly higher than in the fixed effects model for direct taxes and customs and somewhat lower for domestic market taxes.

$<$ Table 3: Estimates with instrumental variables. $>$

\footnotetext{
${ }^{31}$ The first stage regression for the interaction term is not of interest in itself and thus not reported. We have included women's suffrage, polity IV dummy, proportional rule and left-wing party share in the first stage regressions as required to obtain consistent estimates. Moreover, if the interaction term is used as an instrument in the sub-model for the size of government, the Hansen $J$ test rejects overidentification.
} 


\subsection{Other Results}

Table 2 (and 3) report a number of other results that deserve comment. We shall focus mainly on the four political control variables, but also briefly comment on the economic control variables. The discussion is based on Table 2 .

Women's suffrage Several countries (Denmark, the Netherlands, Norway, Sweden, and Germany) introduced (full) women's suffrage around World War I followed by the United Kingdom in $1928 .^{32}$ Italy, Belgium, and France allowed females to vote after World War II, and the last country in Western Europe to give the vote to women was Switzerland in 1971. A likely fiscal consequence of women's suffrage is an increase in the demand for social insurance (Lott and Kenny, 1999). This is because married females who are specialized in household production, in case of breakdown of marriage or widowhood, find it difficult to enter or reenter the labour market. This group of voters therefore supports a tax system that provides insurance against this risk and would, accordingly, favor relatively high marginal and average taxes on income (Varian, 1980) and public spending on social insurance programs. This would, ceteris paribus, lead to an increase in the share of direct taxes and more overall government spending. The estimated positive impact of women's suffrage on the share of direct taxes reported in Table 2 is consistent with this. The negative effect of women's suffrage on total spending and taxation is more surprising, but mainly reflects a negative association with spending on arms and defense (Aidt et al., 2006). Aidt and Dallal (2006) show that when the delayed impact on female election turnout is taken into account, women's suffrage did have the expected positive impact on social spending in Western Europe, as it had in US states (Lott and Kenny, 1999).

Political competition From the estimated coefficient on the polity IV dummy in Table 2 , we observe that political competition reduces total public spending, increases total tax revenues, increases the share of direct taxes and reduces the share of market taxes. These

\footnotetext{
${ }^{32}$ Women of age 30 or above and who were householders or wives of householder were allowed to vote in the United Kingdom for the first time in the election in 1918, but it was not until 1928 that all adult women were allowed to vote.
} 
effects are very different from those of the franchise extension itself. We, therefore, note that political participation and competition capture two different dimensions of democracy.

Proportional rule Theoretical work by, e.g., Persson and Tabellini (2000, chapter 8 and 9), Austen-Smith (2000), Lizzeri and Persico (2001) and Milesi-Feretti et al. (2002) predicts that proportional rule should be associated with higher spending on public goods and possibly also with higher overall spending and taxation. The logic is that the constituency of government is broader under proportional rule and this makes it relatively more efficient for governments to deliver public goods than to please voters with targeted transfers. We find a strong negative impact on total spending and taxation and that proportional rule shifts taxation away from direct taxes and customs towards market taxes. The first effect was also reported in Aidt et al. (2006) and contrasts with postwar evidence (Persson and Tabellini, 2003, chapter 6; Milesi-Feretti et al., 2002). The second effect is consistent with theory insofar as the burden of market taxes was shared by the entire population and the constituency of government was best served under proportional rule by spreading the tax cost thinly across many taxpayers.

Left wing parties The share of parliament seats held by left-wing parties has a negative impact on total spending and taxation, no impact on the share of direct taxes, but shifted indirect taxation away from market taxes to customs. The first effect is somewhat surprising and stands in contrast to evidence from the post World War II period where the strength of left-wing parties is often, but not always, found to correlate positively with redistributive policies and the size of government (see, for example, Hicks and Swank, 1992; Blais et al. 1993). The effect on the tax structure is consistent with the view that left-wing parties are more protectionist.

Economic and demographic control variables We note from Table 2 that education attainment is positively associated with total tax revenues (and total spending). This gives some confidence that the variable is picking up aspects of tax collection technology rather than inequality effects. The forces of development as captured by GDP and urbanization 
have the expected positive impact on government spending, while the "grey power" effect discussed by Lindert (1994) and captured by old comes through only as higher tax revenues. In the tax share model, we notice the GDP per capita mainly affects the composition of indirect taxes, with a positive impact on the share of market taxes and a corresponding negative impact on the share of customs. This is consistent with the notion that GDP per capita is positively correlated with the size of the tax base on which market taxes are levied. Urbanization and "grey power" have the opposite effect. The negative impact of urbanization on the share of market taxes is inconsistent with the predicted tax base effect, but the result may indicate a tendency for the tax structure, as the size of the agriculture sector diminishes, to shift in favor of tariff protection in favor of influential farmer special interests.

\section{Robustness Checks}

As mentioned above, one may be concerned that our estimates suffer from omitted variable bias. One potentially important omitted factor is the extent of international trade. The volume of trade affects tax shares by affecting revenues from tariffs and other trade-related taxes and total government spending by creating a demand for insurance (Rodrik, 1998) while at the same time be driving democratization (Lopez-Cordova and Meissner, 2005). We have not been able to obtain a consistent measure of trade volumes that covers the whole period, but we have a separate measure of the sum of imports and exports relative to GDP (trade volumes) for the period till 1910 and for the interwar period. ${ }^{33}$ The fact that we have to split the sample into two is less than ideal as we lose much of the time series variation in suffrage and are unable to control for women's suffrage before World War I and for polity IV index after. The results are nonetheless reported in Table 4 . The results obtained are similar to the ones obtained from the full data set for the period till 1910, though the point estimates are somewhat different. Trade volumes itself has a positive, significant effect on customs revenues and a negative effect in the other equations. For the spending equation, one still obtains a positive coefficient on suffrage, but this is no

\footnotetext{
${ }^{33}$ These measures were kindly provided by Chris Meissner (see Lopez-Cordova and Meissner, 2005).
} 
longer so in the tax revenue equation. For the interwar period, the estimates are still of the same sign as before, but the cut-off for the enrollment rate is now out of sample. Trade volumes itself has a negative coefficient in the customs equation for this period. Overall, we conclude that the main thrust of the analysis is robust to controlling for openness but the effects of the franchise extension is harder to detect during the interwar period. This is not surprising as there is little time series variation left in suffrage after 1920.

$<$ Table 4: Estimation controlling for international trade, before 1910 and for 19201938.>

We have performed a number of additional robustness checks (not reported). ${ }^{34}$ First, we have added Germany to the sample and find that the results remain unchanged for the tax share model and the spending equation, but for the tax revenues equation, we find a positive, but insignificant coefficient on suffrage. Second, one may be concerned that enrollment rates affect tax collection capability only with a very long lag. We have, therefore, tried to lag enrollment rate by 10 and 20 years, and find that the results are very similar to those reported in Table 2 . Third, we also find that the results are very similar when one country is dropped one at a time. The coefficients of suffrage and the interaction term are similar to those reported in Table 2 in all these sub-samples in the tax share equations. Suffrage is, however, not always significant in the total spending and taxation equations, but the sign is always positive. Fourth, the tax share model explains how total revenue is divided up between different revenue sources. We have argued in section 3 that spending needs trigger revenue needs and it could, therefore, be argued that the tax structure (as well as the total revenues from each source) is affected directly by spending needs and that a measure of government size belongs to the tax share model. To investigate this issue empirically, we add total central government spending as a proportion of GDP $(G / Y)$ to the tax share model and find that the estimated coefficient is negative and significant in the regression for the share of direct taxes and positive in the others. More importantly, the coefficients on suffrage and on the interaction between suffrage and

\footnotetext{
${ }^{34}$ The full set of extra regressions is available upon request.
} 
enrollment rate are virtually unaffected by adding $G / Y$ and very similar to those reported in Table 2. It is, however, problematic to control for the size of government in the tax share model. Firstly, we lose 42 years of observations for Belgium pre-1912. Secondly, government spending is itself an outcome variable, partly determined by the franchise and administrative costs, so it is undesirable to include it in a 'reduced form'. For these reasons, we decided to report the results without $G / Y$ in Table 2. Fifthly, arguably, it takes some time for changes in the composition of the electorate and reductions in tax collection costs to affect fiscal outcomes. To allow for this possibility, we have reestimated the fiscal model using three years lags (approximately an election period) of suffrage and enrollment rate. The results for the tax share model are very similar to those reported in Table 2, although the critical values $\left(\frac{-\alpha_{1}^{j}}{\alpha_{3}^{j}}\right)$ are slightly larger. Suffrage continues to have a significant positive impact on government spending, but falls below conventional significance levels in the regression for total tax revenues. Sixthly, the degree of income or wealth inequality may be related both to the franchise extension and to fiscal outcomes. Standard inequality indicators of an quality that allows statistical analysis are not available for our sample period. Vanhanen (2003), however, proposes that family farms as a percentage of the total cultivated area or the total area of farm holdings can be used as a crude measure of wealth (or resource) equality. Including this measure in the fiscal model does not change any of our results, and while resource equality is positively associated with the share of direct taxes and market taxes and negatively related to customs, it is not significantly related to neither the size of government nor to the franchise extension.

A number of econometric robustness checks have also been implemented. Firstly, it is possible that the errors are correlated between the estimated equations. Therefore, we reestimated by SURE (Seemingly Unrelated Regressions), and find that this correction makes no difference for the results. Secondly, we have reestimated the model allowing for a common auto regressive process in the error terms. The model for the tax shares requires that the autocorrelation parameter is the same for all three equations. We employed a two-step procedure in which we first used the Cochrane-Orcutt transformation of the variables. We obtained the common autocorrelation parameter from the residuals from 
the OLS regressions for two of the shares and used OLS with PCSEs on the transformed variables. This procedure leads to virtually the same parameter estimates as the ones reported in Table 2. Both procedures produce consistent parameter estimates, and it is reassuring that the results do not change much. We used the same procedure for the government spending equation and the tax share equation, and again obtained similar results to those reported in Table 2 .

\section{Discussion and Conclusion}

Our analysis supports the conclusion that the franchise extension in Western Europe contributed to the growth in government spending and taxation and to a shift towards more direct taxation, but that the latter effect is conditional on relative tax collection costs. These conclusions are consistent with the theoretical prediction discussed in section 3 . The first conclusion is relatively uncontroversial and is supported by many other empirical studies. The second is based on our interpretation of enrollment in primary education as a proxy for the capacity to levy income taxes. One obvious objection to this is that education might also proxy for inequality: societies in which few individuals can read and write are more unequal, not just in terms of opportunities, but also in terms of wealth and income than societies with better educated populations. We note that education as a proxy for equality should be negatively related to total tax revenues. The relationship is, in fact, strongly positive (Table 2) suggesting that our interpretation does have merit. Finally, as discussed in Section 6 the results are robust to include a (crude) measure of equality. Secondly, data from the post war period show a positive association between election turnout and education (see, e.g., Radcliff, 1992). Education attainment could, therefore, proxy for election turnout. However, this interpretation can be ruled out as enrollment rate continues to have the effect shown in Table 2 when we control for election turnout. ${ }^{35}$ Thirdly, Peltzman (1980) argues that education can be a proxy for the ability of beneficiaries of redistribution to process information and to articulate their interest in the political process. Our results are consistent with this interpretation and we cannot

\footnotetext{
${ }^{35}$ The results are available upon request.
} 
statistically discriminate between the two. However, we believe that the tax collection cost story makes more sense in our context: broad-based income taxation must await the accumulation of basic human capital, but given that, it is plausible that the newly enfranchised groups find it easier to articulate political support for redistributive taxation where educational attainment is high.

We have focused on the impact of the franchise extension on spending and taxation in this paper, but the discussion in section 5.3 highlighted some puzzling results related to the effect of women's suffrage, the election rule and left-wing parties on fiscal outcomes. It would be of interest to investigate each of these in more detail in future research (see Aidt and Dallah, 2006).

\section{Data Appendix}

The following notation is used:

1. $T_{1}$ is central government revenues from direct taxes. The definitions of the direct taxes are as follows (Flora et al. (1983: vol. I, p. 257):

(a) Income tax: all modern forms of income taxation. The tax may be levied on total income derived from different sources or for each income source separately. The tax rates are normally directly progressive, or, because of tax free allowances, indirectly progressive.

(b) Property tax: Separate form of taxation on income derived from property.

(c) Inheritance tax: Taxes on legacies and donations. The tax is typically progressive depending on the amount of the legacy or donation.

(d) Extra-ordinary taxes: Taxes on incomes and profits above a normal level which have been earned due to special circumstances such as war or economic crisis.

(e) Assessed taxes: A form of "indirect" taxation of income and property, especially in the nineteenth century, on the basis of "external factors" such as the number of servants, horses, carriages, houses, cattle etc.

(f) Land tax: Taxes levied on earnings from landed property. Originally a tax on agricultural earnings which was later extended to earnings from real estate.

(g) Trade tax: Taxes levied on earnings from trade and industry. In cases where enterprises were not obliged to keep accounts, earnings were frequently estimated on the basis of the number of employees or other characteristics. As a rule the socioeconomic circumstances of the taxpayer were not taken into account. 
(h) Corporation tax: Taxes on the profits of enterprises obliged to maintain a comprehensive book-keeping system. Profits paid out were frequently taxed at a different rate than those which were not.

(i) Other objective taxes: Mostly minor forms of direct taxation that differed from country to country. Extra-ordinary taxes are included here if they show no aspect of income taxation.

2. $T_{2}$ is central government revenues from customs.

3. $T_{3}$ is central government revenues from market taxes. This includes revenues from excise duties and turnover taxes.

4. $T$ is total central government tax revenues in current domestic prices.

5. $G$ is total central government spending in current domestic prices.

6. $Y$ is nominal GDP (or NNP if GDP numbers were not available).

7. gdp per capita is real GDP at international 1985 US relative prices, adjusted to exclude the impact of border changes, per capita.

8. old is the fraction of the population above 65 years of age.

9. urbanization is the proportion of the population that lives in towns with more than 10,000 inhabitants.

10. enrollment rate is primary school enrollment of 5-14 year old as a percentage of all individuals in that age group.

11. suf frage is the electorate in percentage of the enfranchised age and sex group, before the women's suffrage, male population only (parliamentary elections).

12. women's suffrage is a dummy variable equal to 1 in each year after women's suffrage and equal to 0 in each year before that (parliamentary elections)

13. proportional rule is a dummy variable equal to 1 in each year when the election rule is proportional rule and 0 otherwise.

14. polity $I V$ index is an index of political competition, ranging from -10 to +10 . The polity IV dummy is equal to 1 if the polity IV index is positive and equal to 0 otherwise.

15. Trade volumes is exports plus imports relative to GDP.

16. Left-wing party share is the share of seats held by left-wing parties in parliament.

17. Revolution is a dummy variable coded 1 is an actual or attempted revolution took place somewhere in Europe in the that year. 
Data sources The data on the extension of the franchise are from three main sources: Flora et al. (1983), Marshall and Jaggers (2000), and Cook and Paxton (1998). The data on the share of seats held by left-wing parties is constructed from Caramani (2000) and Flora et al. (1983). The economic data is from Flora et al. (1983), Mitchell (1998), and Maddison (1991, 2003). Tax and public spending data are from Flora et al. (1983). The data on real GDP at international prices are from Maddison (2003). Trade data are from Lopez-Cordova and Meissner (2005).

Construction of the data sets used in the regression analysis The original data contains gaps for some of the independent variables. For suffrage and left-wing party share these gaps arise because these political data are only recorded in election years. In offelection years, we have no observations. For suffrage, we have made the assumption that the variable stayed constant between elections, something which is obviously true for the left-wing parties' share of seats. For the economic (control) variables with missing data (enrollment rate, old, urbanization) we have interpolated linearly the missing observations. For most countries, the data on the tax shares are complete as are the series for GDP per capita, but, in the few cases, where data is missing we have interpolated linearly. The same procedure has been used to fill in the gaps in the series for total spending and taxation. Linear interpolation seems a reasonable solution, although more sophisticated methods are available. Little (1992) suggests, for example, to use predicted values from least squares regressions in which the other explanatory variables available in the data set are used as regressors to fill in the gaps. For most variables, we, however, have too few observations to make this a sensible procedure and we did not pursue this alternative.

\section{References}

[1] Acemoglu, D., Robinson J.A., 2000. Why Did the West Extend the Franchise? Democracy, Inequality, and Growth in Historical Perspective. Quarterly Journal of Economics 115(4), 1167-1199.

[2] Aidt, T.S., Dutta, J., Loukoianova, E., 2006. Democracy Comes to Europe: Franchise Extension and Fiscal Outcomes 1830-1938. European Economic Review 50, 249-283.

[3] Aidt, T.S., Dallal, B., 2006. Female Voting Power: The Contribution of Women's Suffrage to the Growth of Social Spending in Western Europe (1869-1960). Unpublished working paper, Faculty of Economics, University of Cambridge.

[4] Austen-Smith, D., 2000, Redistributing Income Under Proportional Representation. Journal of Political Economy 108, 1235-1269.

[5] Beck, N., Katz, J.N., 1995. What to Do (and Not to Do) with Time-Series CrossSection Data. American Political Science Review 89(3), 634-47. 
[6] Becker, G.S. and Mulligan, C.B. 2003. Deadweight Costs and the Size of Government. Journal of Law and Economics XLVI, 293-340.

[7] Blais, A. Blake, D., Dion, S., 1993. Do Parties Make a Difference? Parties and the Size of Government in Liberal Democracies. American Journal of Political Science $37,40-62$.

[8] Boadway, R. and Marchand, M., 1995. The Use of Public Expenditures for Redistributive Purposes. Oxford Economic Papers 47, 47-59.

[9] Boix, C., 2001. Democracy, Development, and the Public Sector. American Journal of Political Science 45(1), 1-17.

[10] Boix, C., 2003. Democracy and Redistribution. Cambridge University Press, Cambridge, UK.

[11] Borge, L-E. Rattsoe, J. 2004. Income Distribution and Tax Structure: Empirical Test of the Meltzer-Richard Hypothesis. European Economic Review 48, 805-826.

[12] Caramani, D., 2000. Elections in Western Europe Since 1815: Electoral Results by Constituencies. Basingstoke, Macmillian Reference.

[13] Carstairs, A.M., 1980. A Short History of Electoral Systems in Western Europe. George Allen \& Unwin, London.

[14] Congleton, R.D. 2004. Economic Development and Democracy, Does Industrialization Lead to Universal Suffrage? Homo Economicus 21, 283-311.

[15] Cook, C., Paxton J., 1998. European Political facts. MacMillan Press, London.

[16] Coughlin, P.J. and Nitzan, S., 1981. Electoral Outcomes with Probabilistic Voting Nash Social Welfare Maxima. Journal of Public Economics 15, 113-22.

[17] Daunton, M., 2001. Trusting Leviathan: The Politics of Taxation in Britain, 17991914. Cambridge University Press, Cambridge, UK.

[18] Dusek, L. 2006. Are Efficient Taxes Responsible for Big Government? Evidence From Tax Withholding. Unpublished Working Paper.

[19] Flora, P., with Alber, J., Eichenberg, R., Krausm, J.K.F., Pfenning, W., Seebohm, K., 1983. State, Economy and Society 1815-1975. Campus Verlag, Frankfurt, Germany.

[20] Greene, W.H.., 2000. Econometric Analysis. Prentice Hall.

[21] Hettich, W., Winer, S., 1988. Economic and Political Foundations of Tax Structure. American Economic Review 78, 701-12.

[22] Hettich, W., Winer, S., 1991. Debt and tariffs: An Empirical Investigation of the Evolution of Revenue Systems. Journal of Public Economics 45, 215-242 
[23] Hettich, W., Winer, S., 1999. Democratic Choice and Taxation: A Theoretical and Empirical Analysis. Cambridge University Press, Cambridge, UK.

[24] Husted, T.A., Kenny, L.W., 1997. The Effect of the Expansion of the Voting Franchise on the Size and Scope of Government. Journal of Political Economy 105, 54-82.

[25] Hicks, A.M., Swank, D.H., 1992. Politics, Institutions, and Welfare Spending in Industrialized Democracies, 1960-82. The American Political Science Review 86, 658-674.

[26] Janowitz, M., 1976. Military Institutions and Citizenship in Western Societies. Armed Forces and Society 2(2), 185-203.

[27] Justman, M., Gradstein, M., 1999. The Industrial Revolution, Political Transition, and the Subsequent Decline in Inequality in 19th-Century Britain. Explorations in Economic History 36, 109-127.

[28] Kau, J.B., Rubin, P.H., 1981. The Size of Government. Public Choice 37, 261-274.

[29] Kenny, L., Winer, S., 2006. Tax Systems in the World: An Empirical Investigation Into the Importance of Tax Bases, Administrative Costs, Scale and Political Regime. International Tax and Public Finance 13, 181-215.

[30] Lindert, P.H., 1994. The Rise in Social Spending 1880-1930. Explorations in Economic History 31, 1-37.

[31] Lindert, P.H., 2004a. Growing Public: Social Spending and Economic Growth Since the Eighteenth Century. Vol 1. Cambridge University Press, Cambridge, UK.

[32] Lindert, P.H., 2004b. Growing Public: Social Spending and Economic Growth Since the Eighteenth Century. Vol 2. Cambridge University Press, Cambridge, UK.

[33] Lipset, S.M., 1960. Political Man: The Social Basis of Modern Politics. New York: Doubleday.

[34] Little, R.J.A., 1992. Regression with Missing X's: a Review. The Journal of the American Statistical Association 87(420), 1227-1237.

[35] Lizzeri, A., Persico, N., 2001. The Provision of Public Goods Under Alternative Electoral Incentives. American Economic Review 91(1), 225-39.

[36] Lizzeri, A., Persico, N., 2004. Why Did the Elites Extend the Suffrage? Democracy and the Scope of Government, With an Application to Britain's "Age of Reform". Quarterly Journal of Economics 119(2), 707-765.

[37] Lott, J.R., Kenny, L.W., 1999. Did Women's Suffrage Change the Size and Scope of Government? Journal of Political Economy 107, 1163-1198. 
[38] Lopez-Cordova, J.E., Meissner, C.M., 2005. The Globalization of Trade and Democracy, 1870-2000. National Bureau of Economic Research Working Paper Series, Working Paper 11117. Cambridge, Mass.

[39] Maddison, A., 1991. Dynamic Forces in Capitalist Development: a Long-run Comparative view. Oxford University Press, Oxford, UK.

[40] Maddison, A., 2003. The World Economy: Historical Statistics. OECD, Paris.

[41] Milesi-Feretti, G.M., Perotti R., Rostagno, M., 2002. Electoral Systems and Public Spending. Quarterly Journal of Economics 117(2), 609-657.

[42] Marshall, M.G., Jaggers K., 2000. Polity IV Project. Data set Users Manual. Center for International Development and Conflict Management, University of Maryland [www.bsos.umd.edu/cidcm/inscr/polity].

[43] Mayer, W. 1984. Endogenous Tariff Formation. American Economic Review 74, 970985.

[44] Meltzer, A.H., Richard S.F, 1981. A Rational Theory of the Size of Government. Journal of Political Economy 89(5), 914-27.

[45] Meltzer, A.H., Richard S.F, 1983. Tests of a Rational Theory of the Size of Government. Public Choice 41, 403-418.

[46] Mitchell, B. R., 1998. International Historical Statistics: Europe, 1750-1993. 4th ed., Macmillan Basingstoke, UK.

[47] O'Rourke, K. and A.M Taylor, 2006. Democracy and Protectionism. National Bureau of Economic Research Working Paper Series, Working Paper 12250. Cambridge, Mass.

[48] Peters, G., 1991. The Politics of Taxation. A Comparative Perspective. Basil Blackwell, Oxford, UK.

[49] Persson, T. Tabellini, G., 2000. Political Economics: Explaining Economic Policy. Cambridge, Mass., The MIT Press.

[50] Persson, T., Tabellini, G., 2003. The Economic Effects of Constitutions. Cambridge, Mass., The MIT Press.

[51] Peltzman, S., 1980. The Growth of Government. Journal of Law and Economics 23(2), 209-287

[52] Ritschl, A., 2003. Modern Germany. In: Mokyr, J., (ed.), The Oxford Encyclopedia of Economic History, vol. 2, pp. 409-19. Oxford University Press, Oxford, UK.

[53] Radcliff, B., 1992. The Welfare State, Turnout and the Economy. American Political Science Review 86, 444-56. 
[54] Riezman, R., Slemrod, J., 1987. Tariffs and collections costs. Weltwirtschaftliches Archiv 123, 545-49.

[55] Rodrik, D., 1998. Why do More Open Economies Have Bigger Government. Journal of Political Economy 106, 1997-1032.

[56] Tanzi, V., Schuknecht, L., 2000. Public Spending in the 20th Century. Cambridge University Press, Cambridge, UK.

[57] Tridimas, G., Winer, S.L., 2005. The Political Economy of Government Size. European Journal of Political Economy 21(3), 643-666,

[58] Vanhanen, T., 2003. Democratization: A Comparative Analysis of 170 Countries. Routledge.

[59] Varian, H.R., 1980. Redistributive Taxation as Social Insurance. Journal of Public Economics 14(1), 49-68.

[60] Wagner, A., 1883. Grundlegung der Politischen Oekonomie. 3rd ed.C.F. Winter, Leipzig.

[61] Webber, C., Wildavsky, A., 1986. A History of Taxation and Expenditure in the Western World. Simon and Schuster, New York.

[62] Wooldridge, J.M., 2002. Econometric Analysis of Cross Section and Panel Data. The MIT Press, Cambridge, Mass. 
Table 1: The evolution of total spending and the composition of taxes in 10 Western European Countries, 1860-1938.

\begin{tabular}{|c|c|c|c|c|c|c|c|c|c|c|c|c|}
\hline & \multicolumn{4}{|c|}{ Before 1880} & \multicolumn{4}{|c|}{ 1881-1914 } & \multicolumn{4}{|c|}{$1920-38$} \\
\hline & G/Y & $\mathrm{T}_{1} / \mathrm{T}$ & $\mathrm{T}_{2} / \mathrm{T}$ & $\mathrm{T}_{3} / \mathrm{T}$ & $\mathrm{G} / \mathrm{Y}$ & $\mathrm{T}_{1} / \mathrm{T}$ & $\mathrm{T}_{2} / \mathrm{T}$ & $\mathrm{T}_{3} / \mathrm{T}$ & $\mathrm{G} / \mathrm{Y}$ & $\mathrm{T}_{1} / \mathrm{T}$ & $\mathrm{T}_{2} / \mathrm{T}$ & $\mathrm{T}_{3} / \mathrm{T}$ \\
\hline Belgium & & 32.06 & 13.33 & 54.61 & 13.90 & 27.24 & 16.98 & 55.78 & 23.15 & 32.18 & 15.58 & 52.25 \\
\hline Denmark & 6.50 & 25.30 & 49.60 & 25.10 & 6.06 & 22.27 & 48.60 & 29.13 & 7.52 & 37.12 & 20.01 & 42.87 \\
\hline France & 10.76 & 32.34 & 9.96 & 57.70 & 11.60 & 24.70 & 13.20 & 62.10 & 19.57 & 37.85 & 12.05 & 50.10 \\
\hline Germany & 4.28 & 0.00 & 46.40 & 53.60 & 4.25 & 0.80 & 52.81 & 46.39 & 13.67 & 44.82 & 11.72 & 43.46 \\
\hline Italy & 12.70 & 38.28 & 11.84 & 49.87 & 15.25 & 35.25 & 18.07 & 46.67 & 28.08 & 40.60 & 4.93 & 54.48 \\
\hline Netherlands & & 39.99 & 7.31 & 52.69 & 8.57 & 40.69 & 7.19 & 52.12 & 15.74 & 49.21 & 11.46 & 39.33 \\
\hline Norway & 3.91 & 0.33 & 78.16 & 21.51 & 6.76 & 9.74 & 69.51 & 20.75 & 7.93 & 37.38 & 32.24 & 30.37 \\
\hline Sweden & 5.65 & 25.67 & 43.99 & 30.34 & 6.14 & 16.22 & 43.59 & 40.19 & 9.37 & 29.86 & 21.78 & 48.36 \\
\hline Switzerland & 1.80 & 6.60 & 92.70 & 0.70 & 2.07 & 4.06 & 92.24 & 3.70 & 5.38 & 19.74 & 62.16 & 18.09 \\
\hline UK & 8.95 & 17.37 & 38.09 & 44.54 & 8.14 & 37.74 & 25.33 & 36.93 & 19.79 & 57.05 & 18.53 & 24.42 \\
\hline Average & 6.82 & 20.65 & 42.01 & 37.34 & 7.65 & 21.27 & 41.17 & 37.55 & 14.12 & 39.29 & 21.65 & 39.05 \\
\hline
\end{tabular}

Source: Flora et al. (1983).

Notes: $\mathrm{G}=$ total spending by central government; $\mathrm{Y}=\mathrm{GDP}$ ( or NNP) in current prices; $\mathrm{T}=$ total central government tax revenues; $\mathrm{T}_{1}=$ direct tax revenues; $\mathrm{T}_{2}=$ revenues from customs; $\mathrm{T}_{3}=$ revenues from market taxes (see Appendix for more details). 
Table 2: The main results.

\begin{tabular}{|c|c|c|c|c|c|c|c|c|}
\hline & $(1)$ & $(2)$ & (3) & $(4)$ & $(5)$ & (6) & $(7)$ & $(8)$ \\
\hline Dependent variable: & $\mathrm{G} / \mathrm{Y}$ & $\mathrm{T} / \mathrm{Y}$ & $\mathrm{T}_{1} / \mathrm{T}$ & $\mathrm{T}_{2} / \mathrm{T}$ & $\mathrm{T}_{3} / \mathrm{T}$ & $\mathrm{T}_{1} / \mathrm{T}$ & $\mathrm{T}_{2} / \mathrm{T}$ & $\mathrm{T}_{3} / \mathrm{T}$ \\
\hline \multirow[t]{2}{*}{ Suffrage } & $0.082 * * *$ & $0.018^{* * *}$ & $-0.872 * * *$ & $0.699 * * *$ & $0.174 * * *$ & $-0.866 * * *$ & $0.699 * * *$ & $0.169 * * *$ \\
\hline & [4.41] & [3.69] & {$[7.80]$} & [6.89] & {$[2.80]$} & {$[9.12]$} & {$[7.12]$} & {$[2.63]$} \\
\hline \multirow[t]{2}{*}{ Enrollment rate } & $0.111^{* *}$ & $0.150 * * *$ & $-0.482 * * *$ & $0.660 * * *$ & $-0.178 * *$ & $-0.477 * * *$ & $0.660 * * *$ & $-0.187 * *$ \\
\hline & {$[2.29]$} & {$[8.72]$} & [3.51] & {$[5.28]$} & {$[2.43]$} & [4.28] & {$[5.73]$} & {$[2.48]$} \\
\hline \multirow[t]{2}{*}{ (Suffrage)*(Enrollment rate) } & & & $0.014^{* * *}$ & $-0.011^{* * *}$ & $-0.003^{* * *}$ & $0.014 * * *$ & $-0.011 * * *$ & $-0.003 * * *$ \\
\hline & & & {$[7.35]$} & {$[6.54]$} & {$[2.64]$} & {$[8.64]$} & {$[6.66]$} & {$[2.63]$} \\
\hline \multirow[t]{2}{*}{ Urbanization rate } & $0.626 * * *$ & -0.051 & -0.256 & $1.627 * * *$ & $-1.371 * * *$ & -0.281 & $1.627 * * *$ & $-1.342 * * *$ \\
\hline & [3.96] & [1.11] & {$[1.24]$} & {$[6.04]$} & [8.73] & {$[1.15]$} & {$[6.44]$} & {$[8.10]$} \\
\hline \multirow[t]{2}{*}{ GDP per capita } & $15.802 * * *$ & $-5.382 * * *$ & 0.133 & $-15.894 * * *$ & $15.762 * * *$ & 0.381 & $-15.894 * * *$ & $15.725^{* * *}$ \\
\hline & {$[3.58]$} & [4.81] & {$[0.03]$} & {$[2.85]$} & [5.14] & {$[0.07]$} & [2.95] & {$[4.46]$} \\
\hline \multirow[t]{2}{*}{ Old } & -0.051 & $0.586^{* * *}$ & $-1.504 * * *$ & $2.508^{* * *}$ & $-1.004^{* *}$ & $-1.453 * *$ & $2.508^{* * *}$ & $-1.059 * * *$ \\
\hline & {$[0.20]$} & [5.76] & [2.63] & [3.84] & {$[2.42]$} & [2.57] & [4.29] & {$[2.76]$} \\
\hline \multirow[t]{2}{*}{ Women's suffrage } & $-5.200 * * *$ & $-1.761 * * *$ & 2.764 & $-10.665 * * *$ & $7.902 * * *$ & 2.863 & $-10.665 * * *$ & $7.808 * * *$ \\
\hline & {$[4.36]$} & {$[4.23]$} & {$[1.51]$} & {$[5.64]$} & {$[6.33]$} & {$[1.58]$} & [5.69] & {$[6.36]$} \\
\hline \multirow[t]{2}{*}{ Polity IV dummy } & $-2.447^{* * *}$ & $0.556^{*}$ & $3.665 * * *$ & -0.124 & $-3.542 * * *$ & $3.746 * * *$ & -0.124 & $-3.604^{* * *}$ \\
\hline & {$[2.90]$} & {$[1.74]$} & {$[2.77]$} & {$[0.09]$} & [3.71] & {$[2.63]$} & {$[0.08]$} & {$[3.74]$} \\
\hline \multirow[t]{2}{*}{ Proportional rule } & $-3.375 * * *$ & $-1.462 * * *$ & $-3.941 * *$ & $-4.344^{* *}$ & $8.285^{* * *}$ & $-4.010 * * *$ & $-4.344 * * *$ & $8.424 * * *$ \\
\hline & [3.86] & {$[4.70]$} & {$[2.53]$} & [2.48] & [6.94] & [2.73] & [2.87] & [8.49] \\
\hline \multirow[t]{2}{*}{ Left-wing party share } & $-0.109 * * *$ & $-0.035 * *$ & -0.01 & $0.196 * * *$ & $-0.186 * * *$ & -0.017 & $0.196 * * *$ & $-0.191^{* * *}$ \\
\hline & [3.54] & {$[2.41]$} & {$[0.15]$} & [3.20] & {$[4.38]$} & {$[0.30]$} & [3.37] & {$[5.03]$} \\
\hline Observations & 488 & 488 & 550 & 550 & 550 & 550 & 550 & 550 \\
\hline Number of countries & 9 & 9 & 9 & 9 & 9 & 9 & 9 & 9 \\
\hline Critical value ${ }^{\mathrm{a}}$ & & & 62.29 & 63.55 & 58.00 & 61.86 & 63.55 & 56.33 \\
\hline Estimation technique & PCSE & PCSE & PCSE & PCSE & PCSE & Tobit & Tobit & Tobit \\
\hline
\end{tabular}

Notes: $\mathrm{z}$ statistics in brackets; * significant at $10 \%$; ** significant at $5 \%$; *** significant at $1 \%$; $\mathrm{G}=$ total spending by central government; $\mathrm{Y}=\mathrm{GDP}$ (or NNP)

in current prices; $T=$ total central government tax revenues; $T_{1}=$ direct tax revenues; $T_{2}=$ revenues from customs; $T_{3}=$ revenues from market taxes (see

Appendix for more details). All regressions include a set of war dummies; fixed country effects; 5 years time dummies and a constant term. $\mathrm{a}=$ critical value

is the numerical value of the ration of the coefficient on suffrage and suffrage*enrollment rate. 
Table 3: Estimates with instrumental variables.

\begin{tabular}{|c|c|c|c|c|c|c|c|}
\hline & (9) & (10) & (11) & (12) & (13) & (14) & (15) \\
\hline Dependent variable: & Suffrage & $\mathrm{G} / \mathrm{Y}$ & $\mathrm{T} / \mathrm{Y}$ & Suffrage & $\mathrm{T}_{1} / \mathrm{T}$ & $\mathrm{T}_{2} / \mathrm{T}$ & $\mathrm{T}_{3} / \mathrm{T}$ \\
\hline \multirow{2}{*}{ Suffrage } & & $0.076^{* * * *}$ & 0.01 & & $-0.921 * * *$ & $0.782 * * *$ & $0.139 * *$ \\
\hline & & [3.03] & [1.17] & & [7.29] & [6.11] & [2.16] \\
\hline \multirow[t]{2}{*}{ Enrollment rate } & 0.08 & $0.113^{* *}$ & $0.154 * * *$ & $0.391 * * *$ & $-0.458 * * *$ & $0.621 * * *$ & $-0.163 * *$ \\
\hline & [1.41] & [2.19] & [8.07] & [2.93] & [3.82] & [4.92] & [2.20] \\
\hline \multirow[t]{2}{*}{ (Suffrage)*(Enrollment rate) } & & & & & $0.014 * * *$ & $-0.011^{* * *}$ & $-0.003 * *$ \\
\hline & & & & & [6.61] & [5.41] & [2.47] \\
\hline \multirow[t]{2}{*}{ Urbanization rate } & 0.09 & $0.622 * * *$ & -0.05 & 0.28 & -0.26 & $1.605^{* * *}$ & $-1.348 * * *$ \\
\hline & {$[0.47]$} & [6.15] & {$[1.22]$} & [1.21] & [1.15] & [6.07] & [8.94] \\
\hline \multirow[t]{2}{*}{ GDP per capita } & -1.13 & $15.613^{* * *}$ & $-5.511 * * *$ & -2.54 & -1.52 & -12.98 & $14.501^{* * *}$ \\
\hline & {$[0.23]$} & {$[3.18]$} & [3.61] & {$[0.48]$} & {$[0.18]$} & {$[1.56]$} & [3.90] \\
\hline \multirow[t]{2}{*}{ Old } & -1.05 & -0.07 & $0.547 * * *$ & $-1.351^{*}$ & $-1.688^{* *}$ & $2.961 * * *$ & $-1.273 * * *$ \\
\hline & {$[1.48]$} & [0.19] & {$[4.85]$} & {$[1.71]$} & {$[2.10]$} & {$[3.28]$} & [3.33] \\
\hline \multirow[t]{2}{*}{ Women's suffrage } & 3.16 & $-5.091 * * *$ & $-1.574 * * *$ & $6.870^{* *}$ & 3.72 & $-12.010^{* * *}$ & $8.289 * * *$ \\
\hline & {$[1.34]$} & [4.18] & [3.53] & {$[2.57]$} & [1.51] & {$[5.22]$} & [6.01] \\
\hline \multirow[t]{2}{*}{ Polity IV dummy } & -0.37 & $-2.408 * * *$ & $0.641^{* *}$ & -0.83 & $3.523^{* *}$ & -0.08 & $-3.441^{* * *}$ \\
\hline & {$[0.15]$} & {$[2.90]$} & {$[2.07]$} & [0.39] & {$[2.54]$} & {$[0.05]$} & [3.65] \\
\hline \multirow[t]{2}{*}{ Proportional rule } & $4.95^{* *}$ & $-3.278 * * *$ & $-1.331^{* * *}$ & $4.025^{* *}$ & -2.78 & $-5.984^{* * *}$ & $8.762 * * *$ \\
\hline & {$[2.17]$} & {$[2.63]$} & [3.27] & [2.01] & {$[1.46]$} & [3.08] & {$[7.86]$} \\
\hline \multirow[t]{2}{*}{ Left-wing party share } & 0.04 & $-0.109 * * *$ & $-0.034 * * *$ & $0.220 * *$ & 0.01 & $0.169 * * *$ & $-0.174 * * *$ \\
\hline & {$[0.95]$} & [3.53] & [2.64] & [2.34] & [0.09] & [3.00] & [4.23] \\
\hline \multirow[t]{2}{*}{ Suffrage (lagged) } & $0.81 * * *$ & & & $1.029 * * *$ & & & \\
\hline & [22.67] & & & [10.47] & & & \\
\hline \multirow[t]{2}{*}{ Suffrage (lagged)*(Enrollment rate) } & & & & $-0.005^{* *}$ & & & \\
\hline & & & & [2.39] & & & \\
\hline \multirow[t]{2}{*}{ Revolution } & -0.59 & & & -0.74 & & & \\
\hline & {$[0.34]$} & & & {$[0.45]$} & & & \\
\hline Hansen J-statistic & & 0.17 & 0.34 & & 2.04 & 0.25 & $2.91 *$ \\
\hline First stage F-statistic & $395.84 * * *$ & & & $231.99 * * *$ & & & \\
\hline Observations & 485 & 485 & 485 & 547 & 547 & 547 & 547 \\
\hline Number of countries & 9 & 9 & 9 & 9 & 9 & 9 & 9 \\
\hline Critical value $^{\mathrm{a}}$ & & & & & 67.23 & 71.10 & 51.44 \\
\hline Estimation technique & First stage & 2SLS & 2SLS & First stage & 2SLS & 2SLS & 2SLS \\
\hline
\end{tabular}

Notes: See notes to Table 2. $\mathrm{b}=$ the lag is 3 years. The instruments are 3 years lags of suffrage and revolution. In regressions (13)-(15) we use the interaction between lagged suffrage and enrollment rate as an additional instrument. 
Table 4: Estimation controlling for openness to international trade, before 1914 and1920-1938.

\begin{tabular}{|c|c|c|c|c|c|c|c|c|c|c|}
\hline & \multicolumn{5}{|c|}{ Before 1914} & \multicolumn{5}{|c|}{ The Interwar period } \\
\hline & (16) & (17) & (18) & (19) & (20) & (21) & (22) & (23) & (24) & (25) \\
\hline Dependent variable: & $\mathrm{G} / \mathrm{Y}$ & $\mathrm{T} / \mathrm{Y}$ & $\mathrm{T}_{1} / \mathrm{T}$ & $\mathrm{T}_{2} / \mathrm{T}$ & $\mathrm{T}_{3} / \mathrm{T}$ & $\mathrm{G} / \mathrm{Y}$ & $\mathrm{T} / \mathrm{Y}$ & $\mathrm{T}_{1} / \mathrm{T}$ & $\mathrm{T}_{2} / \mathrm{T}$ & $\mathrm{T}_{3} / \mathrm{T}$ \\
\hline \multirow[t]{2}{*}{ Suffrage } & $0.037 * * *$ & -0.004 & $-0.594^{* * *}$ & $0.303^{* * *}$ & $0.291 * * *$ & $0.183^{*}$ & -0.076 & $-2.315^{* *}$ & -1.517 & $3.832 * * *$ \\
\hline & {$[5.44]$} & {$[0.90]$} & [12.57] & [4.43] & [4.51] & {$[1.68]$} & [1.15] & [2.49] & {$[1.44]$} & [3.48] \\
\hline \multirow[t]{2}{*}{ Enrollment rate } & -0.004 & $-0.017 * *$ & $-0.211 * * *$ & $0.294 * * *$ & -0.083 & $-0.299 * * *$ & $0.226 * * *$ & -0.516 & $-2.527^{*}$ & $3.043 * *$ \\
\hline & {$[0.24]$} & {$[2.15]$} & {$[4.97]$} & {$[4.62]$} & {$[1.42]$} & {$[3.85]$} & [3.59] & {$[0.40]$} & [1.93] & {$[2.12]$} \\
\hline \multirow[t]{2}{*}{ (Suffrage)*(Enrollment rate) } & & & $0.011 * * *$ & $-0.006 * * *$ & $-0.005 * * *$ & & & $0.022^{*}$ & $0.024 *$ & $-0.046 * * *$ \\
\hline & & & {$[12.88]$} & [4.92] & [4.08] & & & [1.78] & {$[1.72]$} & [3.05] \\
\hline \multirow[t]{2}{*}{ Urbanization rate } & $0.124 * * *$ & $0.074 * * *$ & $1.105 * * *$ & $-0.918 * * *$ & -0.187 & 0.061 & -0.206 & $1.716^{* * *}$ & $0.580^{*}$ & $-2.296 * * *$ \\
\hline & [2.91] & {$[2.82]$} & [6.59] & [4.36] & {$[0.80]$} & {$[0.31]$} & {$[1.36]$} & [3.98] & {$[1.85]$} & [7.75] \\
\hline \multirow[t]{2}{*}{ GDP per capita } & -1.848 & $-3.642 * * *$ & $-16.366 * * *$ & $-8.989 *$ & $25.355 * * *$ & $-13.770 * * *$ & $-4.970 *$ & $-24.091 * *$ & -11.908 & $36.000 * * *$ \\
\hline & {$[0.97]$} & [4.19] & [4.49] & [1.86] & [5.59] & [4.17] & [1.93] & [2.44] & [1.41] & [5.18] \\
\hline \multirow[t]{2}{*}{ Old } & 0.067 & 0.04 & 0.05 & $-1.911 * * *$ & $1.861 * * *$ & -0.049 & $0.401 * *$ & 0.155 & $1.035^{* *}$ & $-1.189 * *$ \\
\hline & [0.53] & [0.39] & {$[0.15]$} & [4.08] & [3.75] & {$[0.29]$} & [1.98] & [0.19] & {$[2.25]$} & [1.97] \\
\hline \multirow[t]{2}{*}{ Trade volumes } & -0.02 & -0.011 & $-0.150 * * *$ & $0.159 * * *$ & -0.009 & -0.048 & $0.055^{*}$ & 0.093 & $-0.297 * * *$ & $0.204^{* *}$ \\
\hline & [1.19] & [1.14] & [4.93] & [3.95] & {$[0.22]$} & [1.45] & [1.88] & {$[0.80]$} & [2.99] & [2.45] \\
\hline \multirow[t]{2}{*}{ Women's suffrage } & & & & & & -1.857 & $-1.817^{*}$ & -1.841 & $-4.700 *$ & $6.541^{* *}$ \\
\hline & & & & & & [1.23] & [1.69] & {$[0.50]$} & [1.83] & [2.41] \\
\hline \multirow[t]{2}{*}{ Polity IV dummy } & 0.022 & $0.954 * * *$ & 1.207 & 0.854 & $-2.061 *$ & & & & & \\
\hline & [0.07] & [3.99] & [1.06] & [0.74] & [1.72] & & & & & \\
\hline \multirow[t]{2}{*}{ Proportional rule } & $0.824 * *$ & 0.331 & -0.312 & $-3.477 * *$ & $3.789 * *$ & -0.702 & $2.356 * *$ & -3.029 & $-9.385 *$ & $12.415^{* * *}$ \\
\hline & {$[2.50]$} & [1.03] & {$[0.24]$} & {$[2.48]$} & {$[2.49]$} & {$[0.43]$} & {$[2.16]$} & {$[0.50]$} & {$[1.86]$} & [3.07] \\
\hline \multirow[t]{2}{*}{ Left-wing party share } & $-0.056 * * *$ & $-0.037 * * *$ & $-0.083^{* * *}$ & $0.189 * * *$ & $-0.105^{* * *}$ & -0.034 & $-0.048^{* *}$ & 0.105 & -0.023 & -0.083 \\
\hline & {$[6.70]$} & [4.64] & [3.35] & {$[5.74]$} & {$[2.94]$} & {$[1.05]$} & [2.31] & [1.52] & {$[0.51]$} & {$[1.61]$} \\
\hline Observations & 247 & 247 & 288 & 288 & 288 & 152 & 152 & 152 & 152 & 152 \\
\hline Number of countries & $8^{\mathrm{b}}$ & $8^{\mathrm{b}}$ & 9 & 9 & 9 & $8^{\mathrm{c}}$ & $8^{c}$ & $8^{c}$ & $8^{c}$ & $8^{\mathrm{C}}$ \\
\hline Critical value $^{\mathrm{a}}$ & & & 54.00 & 50.50 & 58.20 & & & 97.05 & 63.21 & 83.30 \\
\hline Estimation technique & PCSE & PCSE & PCSE & PCSE & PCSE & PCSE & PCSE & PCSE & PCSE & PCSE \\
\hline
\end{tabular}

Notes: See notes to Table 2. b=Belgium not in data set because of missing information; $\mathrm{c}=$ Italy not in data set because of too few observations. 
Figure 1: The extension of the franchise in the 10 countries, 1800-1938.
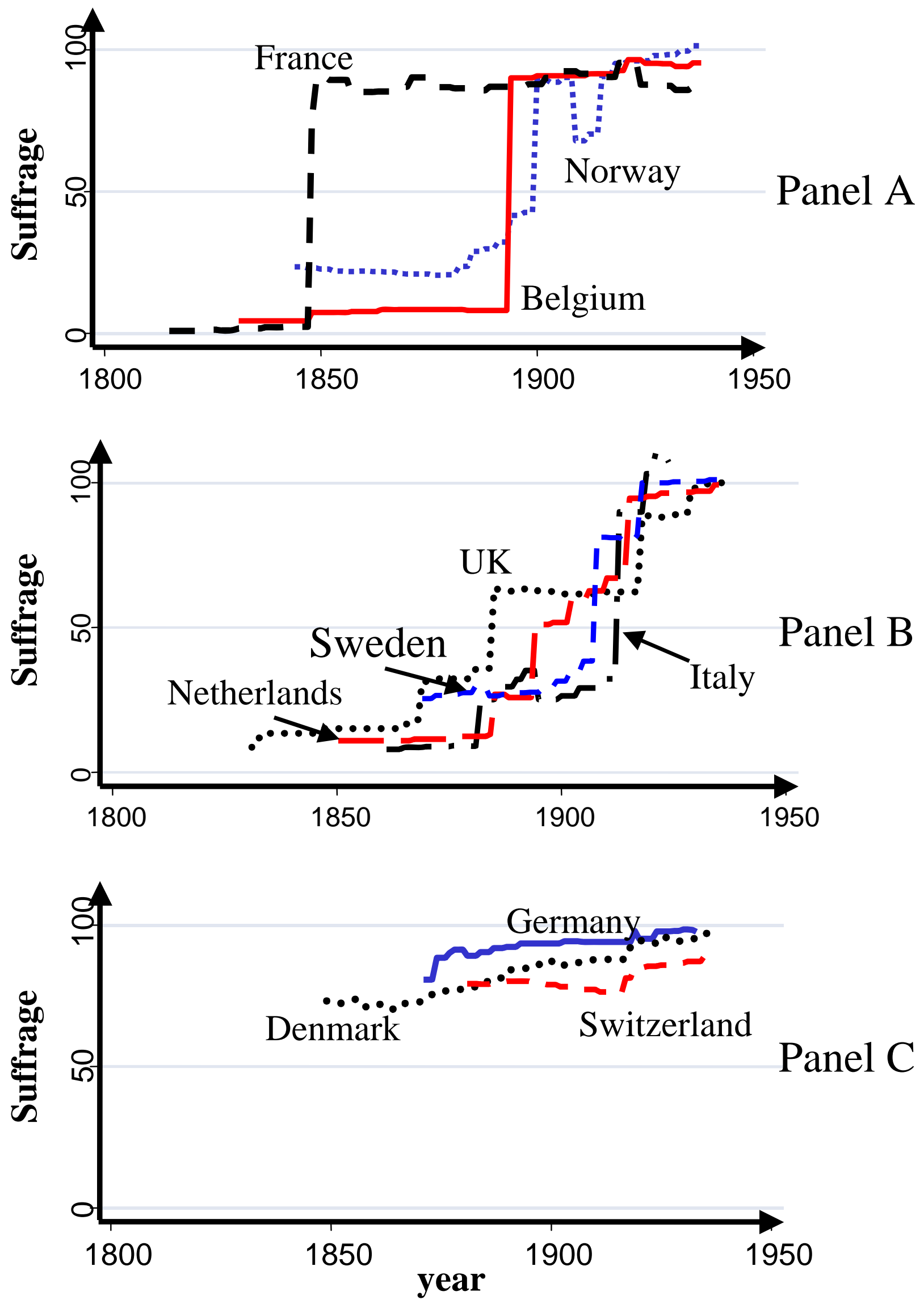

Source: Flora et al. (1983) 
Figure 2: The impact of the extension of the franchise on the share of direct taxes in two hypothetical economies.

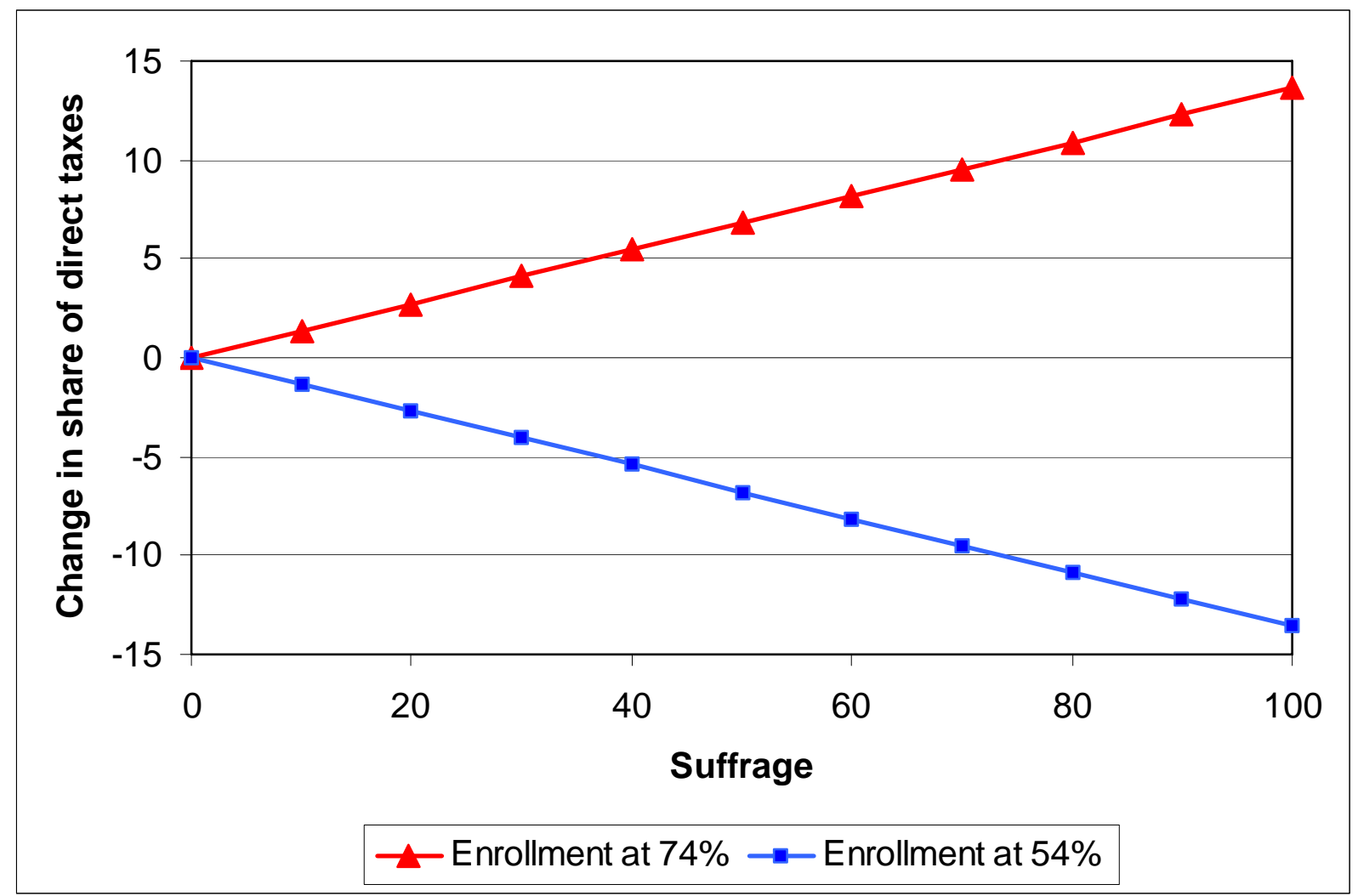

Notes: Constructed from regression (3) in Table 2. 